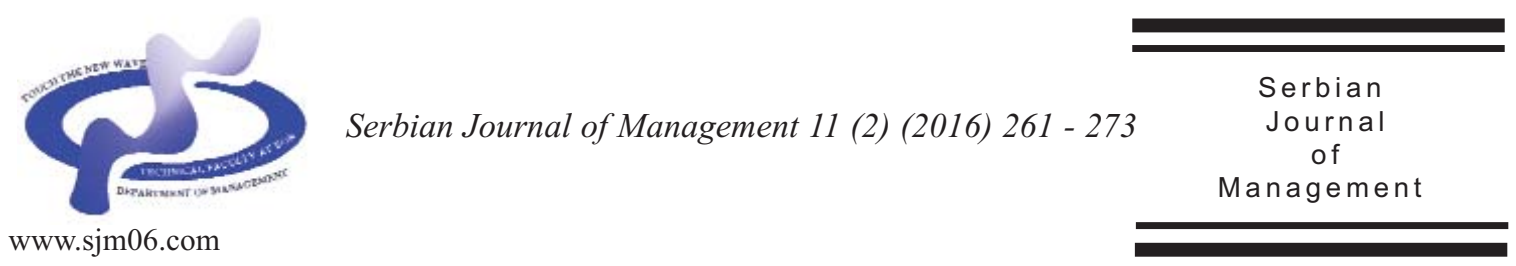

\title{
INFLUENCE OF SUPPLY AND DEMAND FACTORS AT THE DEVELOPMENT OF ENVIRONMENTALLY RESPONSIBLE HOUSING AND UTILITIES SECTOR IN THE RUSSIAN FEDERATION
}

\author{
Natalia B. Safronova, Alexey R. Urubkov, Alexey S. Budakov* and Mikhail Myltsev \\ Institute of sectoral Management, The Russian Presidential Academy of National Economy \\ and Public Administration (RANEPA), \\ Vernadskogo prospect 82, Moscow, Russian Federation
}

(Received 1 June 2016 ;accepted 24 August 2016)

\begin{abstract}
Empirical marketing regional research on supply and demand factors of housing and communal services (HCS) revealed determinants of customer loyalty and satisfaction with the service level and factors influencing on willingness to purchase additional services. Specific features of housing and utilities sector (HUS) as a social significant industry determine requirements to models reflecting reciprocal influence of indices of satisfaction, loyalty and economic indices of operation. The article presents definition of requirements along with development of techniques for modeling influence of satisfaction and loyalty on consumer behaviour of clients. The authors demonstrate trustworthy statistical results of correlative interrelationship of different factors. There have been designed regression models for taking management solutions by executives of management company housing and communal services at the development environmental responsibility. The causes that lead and hamper development of socially oriented services in different regions of the Russian Federation have been identified.
\end{abstract}

Keywords: Service-dominant logic, housing and utilities sector, market potential, range of services, development strategy, environmental assistance

\section{INTRODUCTION}

The housing and communal services provide services essential for creating appropriate environment for the country's population, ensuring reliable functioning of the housing and communal services system is a priority task.

Innovations in services of social sector as important, as innovations in IT-services,

\footnotetext{
* Corresponding author:budakovalexey@gmail.com

DOI:10.5937/sjm11-11166
} 
because of their call to create a high standard of living and consumption in all sectors of the economy. A new paradigm is proposed in (Lusch et al., 2008) by authors, who have been recognized by the scientific community as developers of a new marketing concept. Service-dominant principle based on deep and conceptual understanding of termin «service», which authors interpret as using of specialized competences (knowledge and skills) in the process of business for the benefit of another person (Miles, 2011).

One of the main features of innovation in Social-services sphere is that it does not require large investments and may develop due to the presence of effective demand, unlike industrial sectors (Mandzhieva, 2010).

Service-dominant logic is the basis for developing a strategy of housing and utilities in the Russian Federation. Its key theoretical principles are outlined in (Miles, 2011) and in the works of other authors (Sliniakov, 2013; Tretyak, 2006). Working on the theory and methodology of service activities.

The scientific community has paid great attention to the development of methods for management of service activities, mutually oriented service systems, both in the commercial sphere and in public services.

In traditional marketing research satisfaction, as well as loyalty is a consolidated index that shows, according to the level of significance, general assessment by consumers of various factors affecting their satisfaction with the quality, service, price and image of the company. Such integrated assessment is an indicator of the current level of satisfaction, and it allows to monitor its dynamics, to compare to the competitors, to use the planned values when developing KPI, but does not allow to make quantitative assessment of the impact of definite factors on the achieved level of satisfaction. Also when forming offers to clients in the sphere of housing and utilities sector it is necessary to identify those aspects of the service quality, which are the drivers of loyalty and form the readiness of the client for purchasing additional services.

Practical features of implementing service-dominant principles are considered in (Osborne et al., 2013), which shows the benefits of public services shift to servicedominant logic in building its relationship with clients.

Under the socially oriented services mean specific activity of subjects who have between them in a relationship when in need of social, ecological significance of such a group, a mass, a regular character in the context of the interaction between citizens and service organizations. (Safronova \& Urubkov, 2013).

Next will be the features of the sector of housing and communal services sphere as a specific form of demand and provide suggestions for innovations in the design and implementation environmentally friendly and socially-oriented services.

For the formation of the Russian Federation of ecological culture of resource and energy conservation necessary to have the appropriate market for goods and services. Growing demand for them will increase the investment attractiveness of the industry will lead to a redistribution of public spending on the payment of resources - to their conservation and preservation of the environment.

The current industry position of the housing and utilities is determined by the existence of multiple-structures and the formation of market mechanisms while maintaining a high level of control by the State to monitor the social and economic 
consequences of the reform. Over twenty years of the industry reforms, conditions for competitive relations were formed and the emergence of commercial mechanisms has caused the development of demand and the formation of supply on the market of public services (Solomonov et al., 2015).

The hypothesis of the study is based on the assumption, that the demand for additional services not included to the mandatory list, is defined by such marketing indicators as the satisfaction and loyalty. The proposal of additional services is determined by the existence of the unmet demand, staff capacity and resource potential of housing and communal services providers.

Hypothesis testing has been carried out within the two-stage empirical research on marketing aspects of the activity of management company housing and communal services (MCHCS) that are population services providing additional services, and it has started in 2011 at the Faculty of Real Estate Economics, The Russian Presidential Academy of National Economy and Public Administration (RANEPA). The first phase was aimed at the determination of indicators of satisfaction and loyalty reflecting the quality of management company housing and communal services and evaluation of market potential of additional services, i.e. study of the factors of demand on the market of utilities. Measuring satisfaction and loyalty of the residents of apartment buildings of 8 management company housing and communal services in different regions of Russia was conducted by questionnaire. Assessment of demand indicators was assessed indicator of willingness to purchase additional services provided by (MCHCS), not covered by mandatory payment.

The second stage, which took place in
2014 - 2015, was devoted to the study of (MCHCS) executives' opinion from different regions of the country to provide additional social-oriented services.

Over three hundred of the respondents managers from twenty-one regions of the Russian Federation participated in the survey.

\section{RESEARCH SCOPE}

In Russia household expenditures on housing and utilities sector in average annual income are from 10 to $11 \%$ for families with average income and $15-17 \%$ for families with a low life level. The government takes measures to ensure that the cost of housing does not exceed $20 \%$ of the total family income that is critical for social stability.

The reform of a housing and utilities sector sphere, the formation of a multystructural system in this field of activity, the emergence of private business, establishment of legal regulations for the competition cause the necessity to adapt traditional marketing tools for their application in the emerging market of housing and public services. Liberalization of prices for HUS, even in combination with an active policy of the state control, leads to their growth, which in turn modifies the requirements of the citizens to their quality. Indeed, in the minds of consumers, accustomed to the HUS of market relations, any increase in price for a product or service must be accompanied by the growth of their quantity or quality.

The level of quality of housing and utilities sector varies on the market of management company housing and communal services (MCHCS). For the consumer, due to a lack of real choice 
procedures and experience, it is extremely difficult to determine this level at the time of concluding a collective agreement on the service. Therefore, the indicator of quality can and should be not only objective parameters of the technical specifications for the technological equipment and the services, but also subjective assessment of the consumers.

The cumulative impact of these parameters will determine satisfaction value. The satisfaction is the sum of appropriateness of provided services to the customer's expectations, the company's image, price and quality of the service. There are various ways to estimate this indicator, but at this task was apply the approaches included in the system of international standards of quality management ISO (Self \& Roche, 2011) and the internationally recognized methodology for the evaluation of customer loyalty NPS (Reichheld, 2003).

The grounding of such a choice is given in the preceding article of the authors (Safronova \& Urubkov, 2013). The goal of the research was developing a methodology to measure the dependence of satisfaction, loyalty and dedication indices and readiness for purchasing additional services, as well as identifying factors causing the change of each of these indices. The development and approbation of methods for modeling and research was based on a large number of data collected in the framework of the pilot interregional study of satisfaction with services of (MCHCS) in the field of HUS. These data were included into the questionnaire survey of 500 customers using the services of HUS provided by the management company housing and communal services with different type of organizational form.

\subsection{The algorithm for the quantitative measurement and description of the HUS services market}

To achieve the above mentioned objectives, it was proposed to consider from the management company housing and communal services standpoint of system analysis, choosing as a researched indicator, the readiness to purchase additional services (the variable $y$ ), and highlighting the factors $x_{1}, x_{2}, \ldots x_{m}$, affecting the readiness to purchase additional services (the satisfaction with the quality of already existing services of the $1^{\mathrm{st}}, 2^{\text {nd }}, \ldots, \mathrm{m}$-th) - figure 1 .

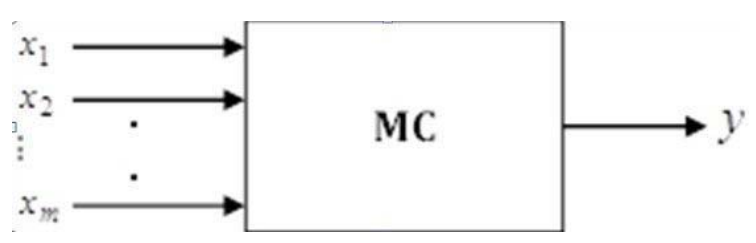

Figure 1. The satisfaction with the quality of already existing services of the $1^{s t}, 2^{n d} \ldots$

Taking such an approach, the readiness can be seen as dependent on these factors the variable $y$. The establishment of the analytical relationships between the researched indicator and factors, as well as assessment of the impact of the factors on it are possible if the indicators are quantitatively measurable.

Then, if statistics is available, for example the statistics of the data of the questionnaire survey of the (MCHCS) customers, it becomes possible:

- using means of correlation analysis to determine which of the factors, and to what extent, affect the analyzed indicator - the readiness to purchase additional services;

- to build a regression model, which will analytically link the analyzed indicator and 
the factors, affecting it;

- to use the built model for investigating "what will be, if...";

- to predict and investigate, on the basis of the model, different options for management decisions, evaluating what consequences they will lead to.

For the quantitative measurement of the indices it was proposed to use the following algorithm transforming qualitative assessment of respondents to quantitative one.

1. On the basis of processing of the questionnaires the histograms are built showing the distribution of the respondents' answers according to the estimate of each factor. An example of such a histogram is show at figure 2 .

2. A quantitative index is put to each assessment, for thisthe qualitative assessment scale is indexed, for example, according to a five-point numerical scale as shown in table 1.

3. The numerical value of the factor xi, characterizing the satisfaction with the quality of the $i$-th service by the surveyed respondents, is calculated on the base of the histogram as a weighed average value. For example, for the distribution of the HUS customers responses assessing satisfaction with the service as shown in Figure 1, the numerical value of the factor xi (satisfaction with the $\mathrm{i}$-th service) will be equal to $\mathrm{xi}$ $=1 \times 0.08+2 \times 0.12+3 \times 0.36+4 \times 0.28+5 \times 0.16=$ 3.32 .

4. A similar procedure for processing the results of the questionnaire is carried out for all factors and for the "variable" dependent on these factors - the readiness to purchase additional services.

Table 1. The index of the qualitative assessment scale

\begin{tabular}{llllll}
\hline Qualitative assessment & $\begin{array}{l}\text { Absolutely } \\
\text { not satisfied }\end{array}$ & $\begin{array}{l}\text { Not } \\
\text { satisfied }\end{array}$ & $\begin{array}{l}\text { Yes And } \\
\text { no }\end{array}$ & Satisfied & $\begin{array}{l}\text { Absolutely } \\
\text { satisfied }\end{array}$ \\
\hline $\begin{array}{l}\text { Quantitative } \\
\text { index }\end{array}$ & 1 & 2 & 3 & 4 & 5 \\
\hline
\end{tabular}

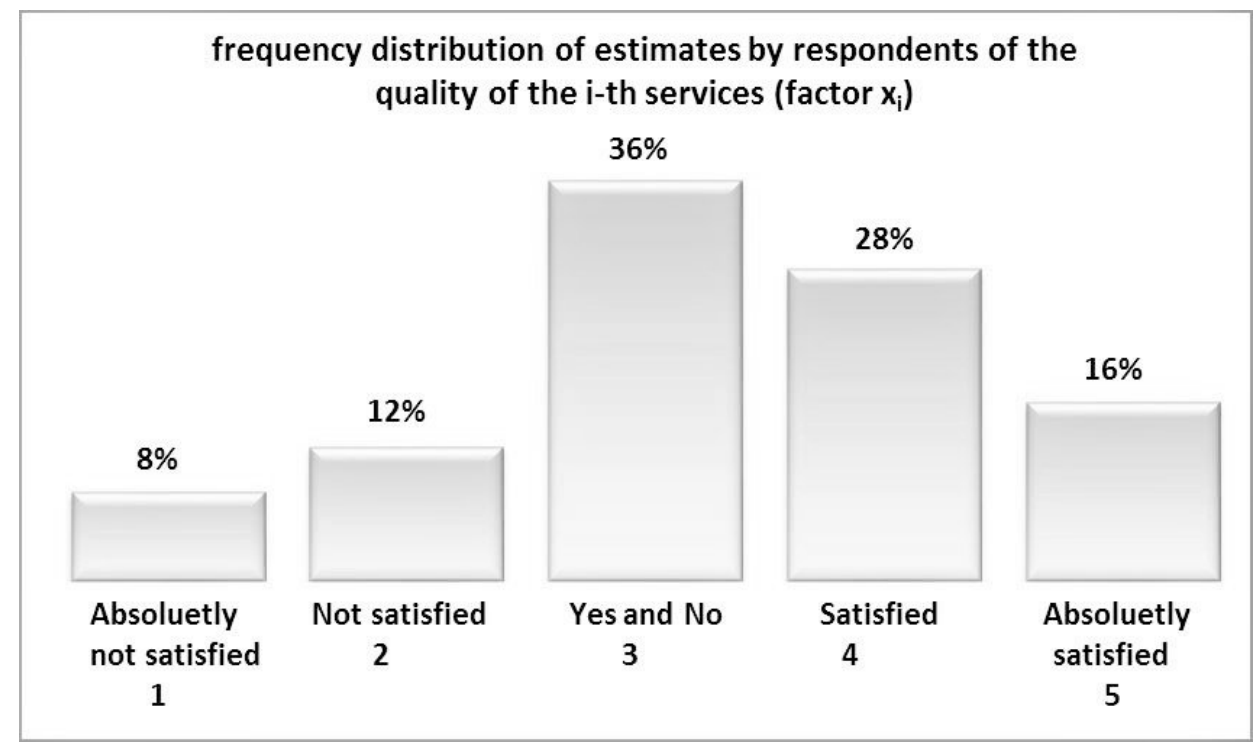

Figure 2. Frequency distribution of estimates by respondents of the quality of the $i$-th services $\left(\right.$ factor $\left.x_{i}\right)$ 
5. The result of transforming the qualitative assessment into the quantitative one - for each j-th company will be a vector of observations $\left[\mathrm{y}, \mathrm{x}_{1}, \mathrm{x}_{2}, \ldots \mathrm{x}_{\mathrm{m}}\right]_{\mathrm{j}}$.

6. After the surveys in several companies, we will get a sample to conduct a full econometric analysis (Urubkov, 2011).

Here are some results that allow to substantiate the effectiveness of the proposed approach for the purposes of the survey of customer satisfaction with housing and utilities sectarian to assess the impact of the satisfaction factors on the readiness to purchase additional services.

On the basis of processing the questionnaires, at the first stage of the described algorithm the of customer responses distributions were built, and then the received data were summarized in the table 2 .

The resulting selection, characterizing the activities of the eight (MCHCS), consists of the quantitatively measured factors and the quantitatively measured dependent variable. This allows then to carry out a complete econometric analysis of management company housing and communal services in the sphere of residential and municipal services.

2.2. Analysis of the influence of satisfaction with the provided services on the readiness to purchase additional services

The most convenient way to detect the influence degree of the factors on the researched variable is a correlation analysis calculation and comparison of pair correlation coefficients of the readiness to purchase additional services and the degree of satisfaction with the quality of one or another provided service. The corresponding correlation coefficients calculated on the basis of sample table 2, are given in table 3 .

All the coefficients of pair correlations are

Table 2. Quantitative assessment of the readiness to purchase additional services (dependent variable y) and satisfaction with the provided services (factors $x_{1}, x_{2}, \ldots, x_{m}$ ) for 8 management company housing and communal services)

\begin{tabular}{|c|c|c|c|c|c|c|c|c|c|c|}
\hline \multirow[b]{2}{*}{$\begin{array}{c}(\mathrm{MC} \\
\mathrm{HCS})\end{array}$} & \multirow[b]{2}{*}{$\begin{array}{l}\text { Readiness } \\
\text { to purchase } \\
\text { additional } \\
\text { services } \\
\text { (y) }\end{array}$} & \multicolumn{9}{|c|}{ Factors - satisfaction with the provided services } \\
\hline & & 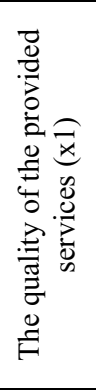 & 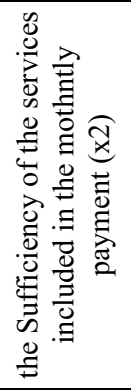 & 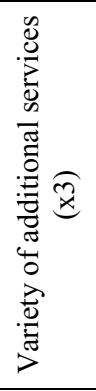 & 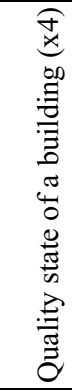 & 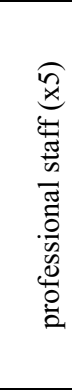 & 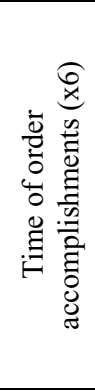 & 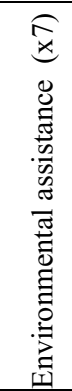 & 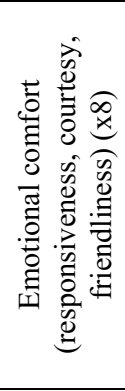 & 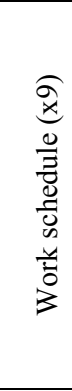 \\
\hline 1 & 2.16 & 3.80 & 3.86 & 3.42 & 4.04 & 3.96 & 3.86 & 4.00 & 3.64 & 4.06 \\
\hline 2 & 2.66 & 3.91 & 4.19 & 3.20 & 3.91 & 4.51 & 4.15 & 4.19 & 4.43 & 4.62 \\
\hline 3 & 2.16 & 4.45 & 4.06 & 4.02 & 4.31 & 4.18 & 4.43 & 4.43 & 4.47 & 4.39 \\
\hline 4 & 2.6 & 3.94 & 4.19 & 3.23 & 3.94 & 4.52 & 4.19 & 4.16 & 4.39 & 4.68 \\
\hline 5 & 2.7 & 3.90 & 4.18 & 3.18 & 4.50 & 3.90 & 4.12 & 4.46 & 4.20 & 4.58 \\
\hline 6 & 1.78 & 3.34 & 3.04 & 2.54 & 3.42 & 2.44 & 3.32 & 3.26 & 3.22 & 3.56 \\
\hline 7 & 2 & 3.53 & 3.43 & $3 . .39$ & 3.73 & 2.61 & 3.67 & 3.51 & 3.47 & 3.63 \\
\hline 8 & 1.7 & 3.32 & 3.08 & 2.56 & 3.40 & 4.40 & 3.92 & 3.52 & 3.48 & 3.82 \\
\hline
\end{tabular}


Table 3. The coefficients of pair correlation of the factors $\left(x_{i}\right)$ with readiness to purchase additional services (y)

\begin{tabular}{|c|c|}
\hline Factor & Coefficients of pair correlation $\left(\mathrm{r}_{\mathrm{yxi}}\right)$ \\
\hline Quality of provided services $\left(\mathrm{x}_{1}\right)$ & 0.6 \\
\hline $\begin{array}{l}\text { Adequacy of services included in the } \\
\text { monthly payment }\left(\mathrm{x}_{2}\right)\end{array}$ & 0.93 \\
\hline A variety of additional services $\left(\mathrm{x}_{3}\right)$ & 0.39 \\
\hline The quality of the state of a building $\left(\mathrm{x}_{4}\right)$ & 0.73 \\
\hline Professionalism of the staff $\left(\mathrm{x}_{5}\right)$ & 0.5 \\
\hline Time of order accomplishments $\left(\mathrm{x}_{6}\right)$ & 0.62 \\
\hline Environmental assistance $(\mathrm{x} 7)$ & 0.81 \\
\hline $\begin{array}{l}\text { Emotional comfort (responsiveness, } \\
\text { courtesy, friendliness) }\left(\mathrm{x}_{8}\right)\end{array}$ & 0.82 \\
\hline Work schedule $(\mathrm{x} 9)$ & 0.91 \\
\hline
\end{tabular}

positive - the higher the consumer additional services is influenced - by assessment of the quality of provided "Adequacy of services" - ryx $x_{2}=0.93$, "Work services - the higher their readiness to schedule" - ryx $=0.91$, "Emotional comfort purchase additional services. And the most of interaction (responsiveness, courtesy, impressive (in descending order), as shown friendliness)" - $\operatorname{ryx}_{8}=0.82$, "Environmental in table 3 , the readiness to purchase

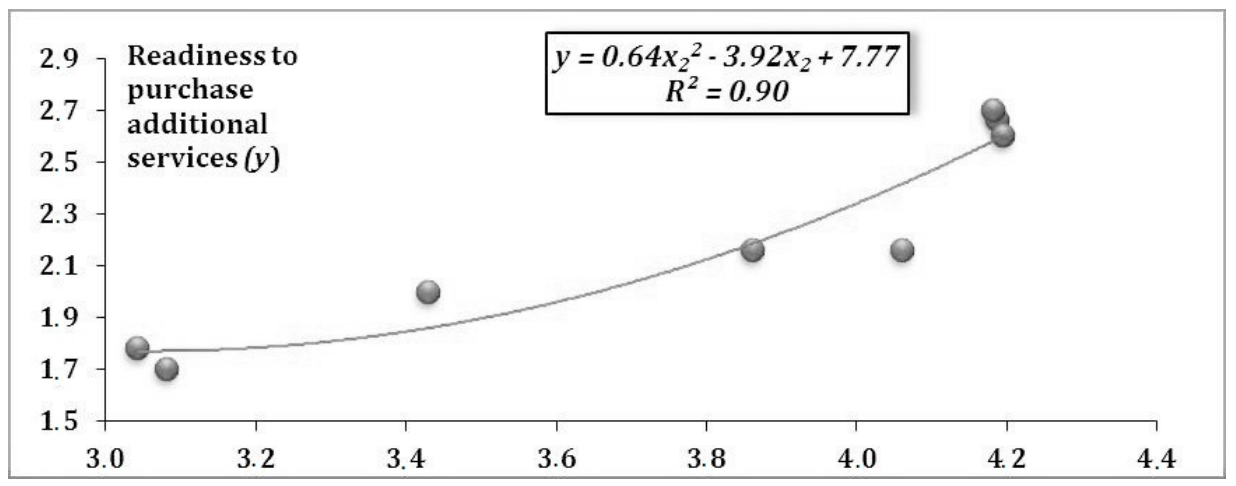

Figure 3. Adequacy of services included in the monthly payment $\left(x_{2}\right)$

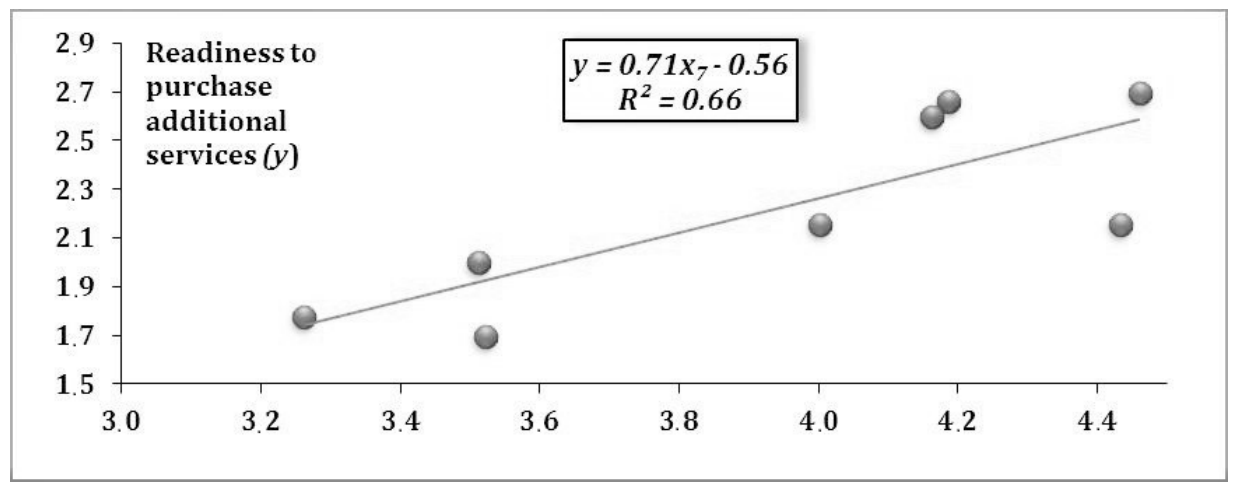

Figure 4. Environmental assistance $\left(x_{7}\right)$ 


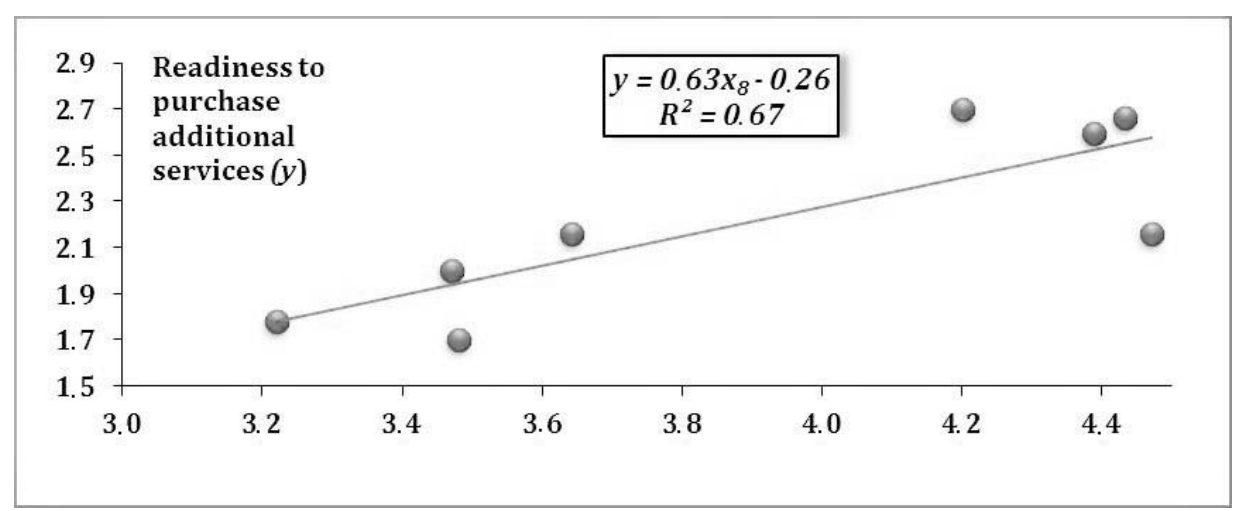

Figure 5. Emotional comfort (responsiveness, courtesy, friendliness) $\left(x_{8}\right)$

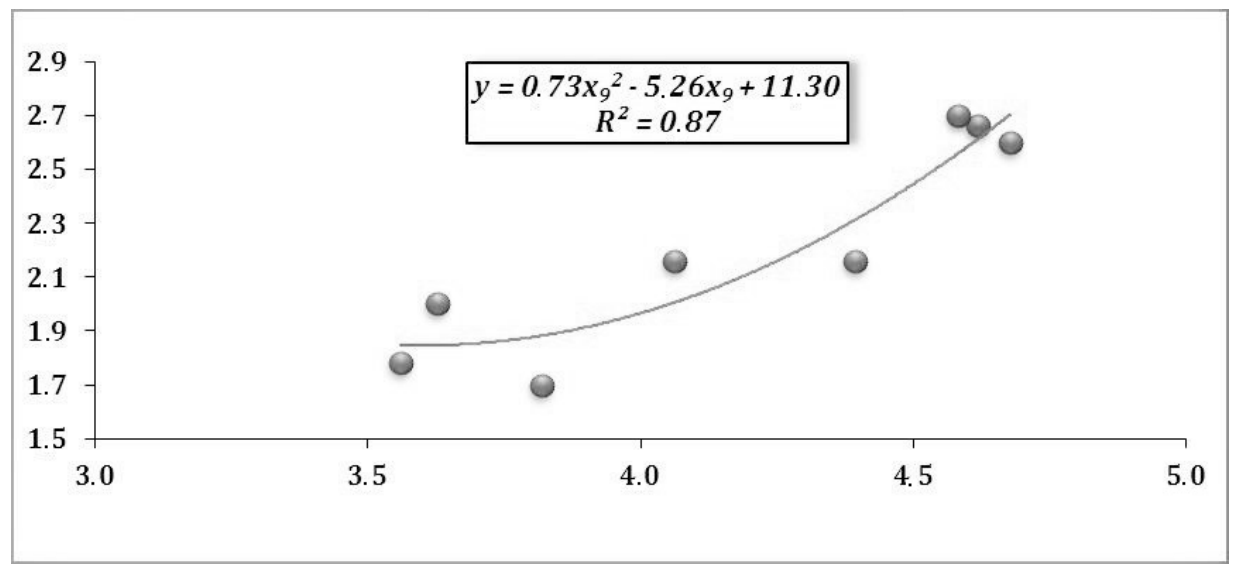

Figure 6. Work schedule $\left(x_{9}\right)$

assistance" - $\operatorname{ryx}_{7}=0.81$, "the Quality of the state of a building" - ryx $_{4}=0.73$.

A more complete picture of the impact of factors on readiness to purchase additional services provide point curves constructed based on sampling (Table 3). Figures 3-6 shows how the four most important factor related to the willingness to purchase additional services. The charts show the trend line and the equation - one-factor regression models. The degree of influence of each factor on readiness to purchase additional services estimated by criterion $\mathrm{R} 2$. The numerical value $\mathrm{R} 2$ in the diagram, is, for example, 0. 90 means that the change in the readiness to purchase additional services index $90 \%$ due to the change of this factor, and $10 \%$ other factors.
Therefore, satisfaction with the quality of these services primarily increases the consumers' readiness to purchase additional services. This conclusion can be used by company management for making decisions, since it shows what levers should be used first.

The proposed method allows to assess not only the level of satisfaction, but also to highlight the factors, which to a greater or lesser extent, affect its formation, and also to estimate (to measure) the degree of this influence. As a result, a manager possesses an effective tool for analysis and improvement of managerial decisions. This method allows to find those economic indices and to influence those activities of (MCHCS), which to the greatest extent form the customers' readiness to purchase 
Table 4. Evaluation of energy conservation introduction of energy-saving equipment

\begin{tabular}{lccccc}
\hline \multirow{2}{*}{\begin{tabular}{l} 
Indicator \\
\cline { 2 - 5 }
\end{tabular}} & $\begin{array}{l}\text { the size of an apartment building } \\
\text { nen }\end{array}$ & $\begin{array}{c}\text { the average } \\
\text { per square } \\
\text { meter }\end{array}$ \\
\hline $\begin{array}{l}\text { Savings through the installation } \\
\text { of customized heat supply } \\
\text { station thousand rubles. }\end{array}$ & 50.5 & 191.2 & 266.8 & 420.7 & 0.050 \\
$\begin{array}{l}\text { Savings due to the installation } \\
\text { of balancing valves, thousand } \\
\text { rubles }\end{array}$ & 0.0 & 53.1 & 48.0 & 75.4 & 0.013 \\
$\begin{array}{l}\text { Savings due to the installation } \\
\text { of thermostats, thousand rubles. }\end{array}$ & 51.0 & 159.4 & 223.1 & 350.6 & 0.042 \\
$\begin{array}{l}\text { Total savings through integrated } \\
\text { automation, thousand rubles. }\end{array}$ & 101.5 & 403.7 & 564. & 888.1 & 0.105 \\
\hline
\end{tabular}

additional services.

As an example of service innovation used in HUS, consider the practice of rendering services on energy saving for the residents of apartment buildings.

Branch of housing and utilities currently is one of the main consumers of energy resources of Russia. The housing and utility sector accounts for about $35 \%$ of total energy consumption in the country, while the HUS has a high potential for energy savings.

The main condition for environmentally responsible development of the market, when introducing basic principles of energy conservation at the state level of the Russian Federation became the Federal law of the Russian Federation approved on 23 November 2009 No. 261-FZ “On energy saving and on increasing energy efficiency, and on amendments to certain legislative acts of the Russian Federation", which established the $\mathrm{f}$ important steps of energy saving.

Thus, raise environmental responsibility the reduction of heat energy consumption due to the installation of complex energysaving equipment can be up to $40 \%$ or approximately $0.072 \mathrm{GCal} /$ year.

From the data given in Table 4 follows that the existence of Environmental support services, which includes services for the installation and operation of energy-saving equipment, is a factor in determining the willingness of homeowners to pay for additional services. Key economic indicators introducing energy-saving equipment should provide data of table 4 .

Calculation of the cost of installing energy-saving equipment was defined as the sum of equipment costs and design and installation work.

The cost of equipment was determined according to the average price books on the market manufacturers.

Analysis of the practice implementation of environmental services of houses was carried out on the example of driving the management company housing and communal services (MCHCS) city Krasnogorsk, Moscow region.

The object of the study was a nine-story four-entrance house with 144 apartments. According to statements by specialists of (MCHCS) city Krasnogorsk, energy consumption in an apartment building in the daytime does not fall to zero, that contributes to the development energy conservation by using solar panels.

Controlling the feed of thermal energy, depending on the weather conditions and its 
Table 5. Calculation of Energy Saving Indicators

\begin{tabular}{lccccc}
\hline \multirow{2}{*}{ Indicator } & \multicolumn{4}{c}{ Area of building (sq. m) } & $\begin{array}{c}\text { Average } \\
\text { index on } \\
\text { sq. m }\end{array}$ \\
\cline { 2 - 5 } & 800 & 4100 & 5500 & 8500 & 0.179 \\
\hline $\begin{array}{l}\text { Calculated level of consumption of thermat } \\
\text { energy before the implementation of } \\
\text { energy efficiency measures, Gcal }\end{array}$ & 218.5 & 695.4 & 959.1 & 1507.4 & \\
$\begin{array}{l}\text { The savings from the introduction of the } \\
\text { automated control assemblies, Gcal }\end{array}$ & 44.7 & 137.1 & 191.9 & 301.9 & 0.036 \\
$\begin{array}{l}\text { The savings from the introduction of } \\
\text { balancing valves, Gcal }\end{array}$ & 0.1 & 34.4 & 48.6 & 75.4 & 0.025 \\
$\begin{array}{l}\text { The savings from the introduction of } \\
\text { thermostats, Gcal }\end{array}$ & 34.8 & 103.8 & 145.9 & 224.6 & 0.027 \\
$\begin{array}{l}\text { The total savings from the implementation } \\
\text { of the above activities, Gcal }\end{array}$ & 81.2 & 284.5 & 401.4 & 601.2 & 0.072 \\
\hline
\end{tabular}

generating, an average helps to reduce its consumption by $20 \%$. It was indicated that while the simultaneous installation of balancing valves and thermostats on heating devices, each event brings about 10-15\% savings.

On the basis of expert evaluation of potential savings from the energy efficient equipment installation, assessment of the estimate of the heat energy savings in natural units has been performed (Table 5).

Thus, the total reduction of energy consumption on average per year is $42 \%$, which is equivalent to 0.072 Gcal per 1 sq. $\mathrm{m} /$ year.

At a joint phased implementation of energy conservation measures, managing companies do not need a one-time major investment, and owners of premises in apartment buildings have the opportunity to assess the environmental performance of additional services.

\section{RESULTS}

The results make it possible to carry out a comparative evaluation of satisfaction and loyalty values for each MCHCS, to assess the effectiveness of various management decisions to improve the quality of services for citizens, to study the dynamics of demand on extra services which allows us to recommend the proposed methodology for management decisions to enhance satisfaction of the users of housing utilities. Assessment of the relationship between different measures of satisfaction was also carried out by correlation analysis (Table 6).

The results shown in table 6 confirmed the existence of a significant relationship between indicators of satisfaction, loyalty, and willingness to purchase additional services - the value of the correlation coefficient is greater than 0.8 . Therefore, the demand for additional services is directly dependent on customer satisfaction. Satisfaction, in turn, generates residents' loyalty.

Table 6. Correlation matrix for Marketing Indicators of (MCHCS) Activity

\begin{tabular}{llll}
\hline & Satisfaction & NPS (\%) & Willingness \\
\hline Satisfaction & 1 & & \\
NPS (\%) & 0.806 & 1 & \\
Willingness & 0.88 & 0.93 & 1 \\
\hline
\end{tabular}




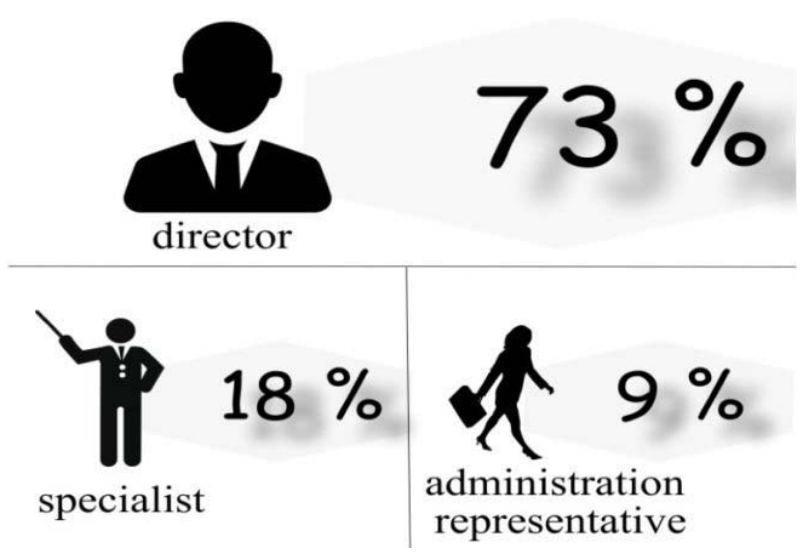

Figure 7. The Distribution of Respondents by Position Held

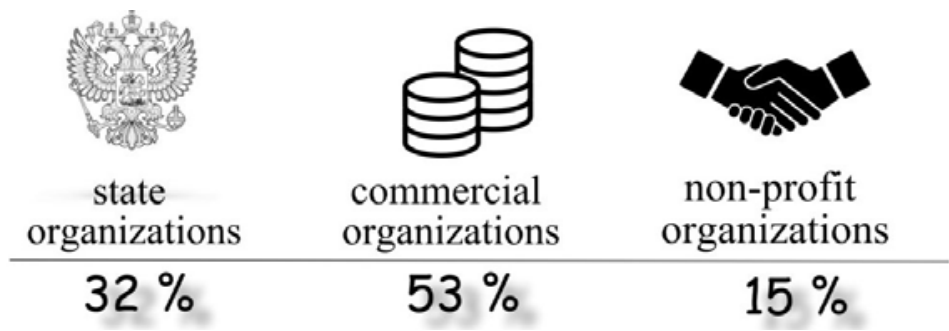

Figure 8. The Distribution of Respondents by Type of Organization

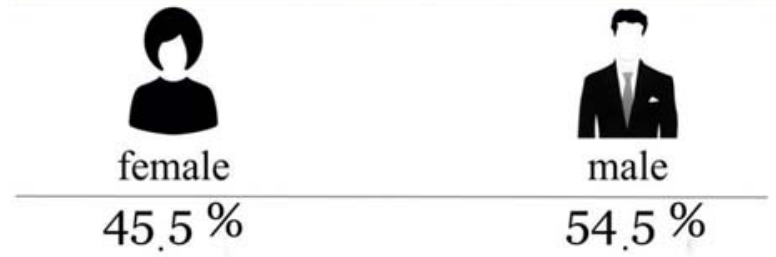

Figure 9. The Distribution of Respondents by Gender

In addition, the analysis indicates the implementation of a customer-oriented strategy in the industry. It was found that there are proposals on the emerging market of additional services, and the rating of the most popular services is defined.

The data on the structure of representative sample is shown in Figures 7 to 9.

The majority of the samples are the first persons in companies (directors, chairmen of MCHCS, municipal service managers). This is the most informed and interested in the development of industry audience, which has credible information.

First, the commercial sector companies are interested in the development of marketbased mechanisms in the industry, thus they prevail in the representative sample. The gender composition of the respondents is shown in Figure 9.

It is noted a slight predominance of males (54\%), that, given the prevalence in the sample executives $(73 \%)$, is quite natural.

The sample included MCHCS from twenty-one regions, the largest number of representatives from the Moscow Region $(18.2 \%)$ and Moscow (13.6\%) and the Republic of Sakha (16.7\%), the Altai Territory (9.1\%) and St. Petersburg (7.6\%). Other regions are represented by $5 \%$ or less 
of respondents. Broad regional coverage of HUS industry implemented in the study allows using the data to produce the development strategy of housing and utilities in the whole country.

\section{CONCLUSION}

The distribution of answers can be concluded that $89.5 \%$ of respondents positively evaluate the development of additional services. Only $10.5 \%$ believe this activity is not promising.

These data are consistent with the fact that all respondents indicated the presence of additional services in management company housing and communal services portfolio, noted a list of possible services, i.e. confirmed the existence of additional services market and appropriateness of its development. Analysis of the causes that reduce the effectiveness of management decisions on the development of additional services showed that the bureaucratic barriers hinder the growth of volumes of additional services (according to 30\% of respondents), despite the fact that only $16 \%$ of management company housing and communal services need more resources for their production.

Construction of regression models by the authors for the 8 researched companies allows partly resolving the dispute.

$$
\text { Willingness }=0.573+0.006 * \mathrm{NPS}+0.02
$$
* Satisfaction

The criterion $\mathrm{R}^{2}$ of the model is quite high (0.91) and shows that the change in index of readiness to purchase additional services (Willingness) by $91 \%$ due to a change «NPS» and «Satisfaction». The average calculation error of index Readiness to purchase additional services does not exceed $5 \%$.

Most of the companies that produce housing and utility services believe there are demand for services, conditions and resources, but the low level of effective demand, personnel and bureaucratic barriers constrain growth of the additional services, which, in turn, prevents the development of servicization processes in the industry.

The results of the research on management company housing and communal services activities in organizing the additional services prove necessity of application marketing indicators in the management of housing and utilities sphere to create favorale conditions for citizens living, increase in the quality of life, and further development of the servicization process in the industry.

The results can be used in the activities of economic entities of different form of ownership for the activities in the municipal institutions to the most effective and complete satisfaction of the population's needs for services aimed at creating a comfortable environment.

\section{References}

Lusch, R.F., Vargo, S.L., \& Wessels, G. (2008). Toward a Conceptual Foundation for Service Science: Contributions from Service-Dominant Logic. IBM Systems Journal, 47 (1), 5-14.

Mandzhieva, D. (2010). The Innovative Strategy of Development of the Service Economy. M.: Dashkov \& Co. (in Russian) Miles, I. (2011). Service Innovation in the Twenty First Century. Foresight Russia, 5 (2), 4-15. 


\title{
УТИЦАЈ ФАКТОРА ПОНУДЕ И ПОТРАЖЫЕ НА РАЗВОЈ ЕКОЛОШКИ ОДГОВОРНОГ СТАМБЕНОГ И КОМУНАЛНОГ СЕКТОРА У РУСКОЈ ФЕДЕРАЦИЈИ
}

\author{
Natalia B. Safronova, Alexey R. Urubkov, Alexey S. Budakov, Mikhail Myltsev
}

\begin{abstract}
Извод
Емпиријско маркетинг истраживање понуде и потражње, регионалног карактера, које се бавило факторима понуде и потражње у области стамбеног и комуналног сектора (ХЦС), показало је однос лојалности купаца према нивоу услуге. Такође, одређени су и фактори који утичу на жељу купаца да плате за додатне услуге. Специфичне особине стамбеног сектора и сектора услуга, као друштвено значајне гране, показују потребе за развојем модела који ће осликавати реципроцитет утицаја индикатора задовољства, лојалности и економских показатеља пословних операција. Овај рад представља дефинисање потреба, заједно са развојем техника за моделовање утицаја задовољства и лојалности на понашање купаца као клијената. Аутори представљају значајне резултате статистичке анализе корелационе повезаности различитих фактора. Развијени су регресиони модели који описују одлуке менаџмента компанија, које се баве стамбеним и комуналним услугама, у смислу развоја еколошке одговорности. Идентификовани су различити случајеви који су водили или успоравали развој друштвено оријентисаних услуга у различитим регионима Руске Федерације.
\end{abstract}

Кључне речи: Услужно - доминантна логистика, стамбено комунални сектор, потенцијал тржишта, опсег услуга, стратегија развоја, еколошка подршка

Osborne, S.P., Radnor, Z., \& Nasi, G. (2013). A New theory for Public Service Management? Towards a (Public) ServiceDominant Approach. The American Review of Public Administration, 43 (2), 135-158.

Reichheld, F.F. (2003). The one number you need to grow. Harvard Business Review, 81 (12), 46-54.

Safronova, N.B., \& Urubkov, A.R. (2013). Modelling the Impact of Satisfaction of Housing Services to Improve the Efficiency of Managing Organizations. Mechanization of Constructing, 5, 17-25. (in Russian)

Self, B., \& Roche, G. (2011). Customer Satisfaction Measurement for ISO 9000: 2000. Routledge, NY.
Sliniakov, V.Yu. (2013). Management in Housing and Utilities. M.: Finance and Statistics. (in Russian)

Solomonov, M.P., Egorov, E.G., \& Turantaev, S.G. (2015). Areas of Reforming Housing and Utilities Sector in Current Environment on Example of Sakha Republic (Yakutia). Mediterranean Journal of Social Sciences, 6 (4), 473-485.

Tretyak O. (2006). Evolution of Marketing: stages, priorities, conceptual framework, the dominant logic. Russian Management Journal, 2, 129-140.

Urubkov, A.R. (2011). Statistical methods and models in business. M.: Delo, RANHiGS. (in Russian) 